\title{
INTERROGATION OF CHILDREN UNDER MALAYSIAN LAWS: A CALL FOR LEGAL REFORM
}

\author{
Amınuddın Mustaffa ${ }^{*}$, Anwar Raof ${ }^{2}$, Mohd Lotpi Mohd Yusob ${ }^{1}$, Asril Amirul Bin Zakariah ${ }^{1}$ \\ ${ }^{1}$ Faculty of Law and International Relations, Universiti Sultan Zainal Abidin, 21300 Terengganu, Malaysia. \\ aminuddinm@unisza.edu.my* (Aminuddin Mustaffa) \\ mohdlotpi@unisza.edu.my (Mohd Lotpi Mohd Yusob) \\ asrilamirul@unisza.edu.my (Asril Amirul bin Zakariah) \\ ${ }^{2}$ Tetuan Anwar Raof \& Co. \\ anwarraof@gmail.com (Anwar Raof)
}

\begin{abstract}
Interrogation is considered one of the critical stages of the juvenile justice process. This process allows the police to question and examine child suspects for the purpose of obtaining information, statement, and evidence for an alleged crime under which they are investigated. While this process undeniably an important aspect of the criminal process, it may turn out to be a stressful and frightening process for children, who are known for their unique incapacities and susceptibility. This paper aims to examine current Malaysian laws and practice on the interrogation of children. It will critically analyze relevant provisions of law as well as existing legal principles on this particular matter. It will also attempt to examine the adequacy of current Malaysian laws in safeguarding the rights and interests of children during the grueling and coerced interrogation process by the police. This article concludes with the recommendation for the reform of current Malaysian laws and practice on the interrogation of children.
\end{abstract}

Keywords: Interrogation-children-, Malaysian law-procedure

Article Received: 18 October 2020, Revised: 3 November 2020, Accepted: 24 December 2020

\section{Introduction}

Each year, thousands of juveniles have been arrested investigated for commission of various crimes. Some of them are investigated for the commission of serious crimes that carry heavy punishment, including incarceration, detention at detention centres and life imprisonment. One of the crucial stages of the investigation process is interrogation. During interrogation, the police are permitted to question, examine, and record confessions and statements from suspected children which may be potentially used against them during the trial. This imminent legal repercussion raises the concern over the adequacy of national law in protecting the rights of children during the interrogation process, in view of the fact that the law has long recognized the fact that children possess distinct cognitive and developmental characteristics compared to adults. Reference to various juvenile justice systems has disclosed that there is a divergence of principles and practice adopted in dealing with this issue.
While some of the juvenile justice systems give due recognition on the need to provide adequate protection to children during the investigation process, others tend to disregard their special susceptibilities and predominantly treats child suspects like adults.

\section{Justification for Protection}

The need to grant children special protection during criminal processes has been the subject of various discussions. Criminal justice has increasingly recognized that criminal processes involving children should be conducted with more care and in a different manner than adults. The root of this argument is primarily based on various tremendous findings by psychologists and scientists on the neurological and cognitive development of children. Over the past quartercentury, there were many studies regarding the neurological and cognitive development of children conducted by psychologists and scientists. Studies have revealed that the brain undergoes 
considerable development during adolescence. The findings of the researches convincingly indicate that the developmental skills acquired by individuals vary from one to another, depending mainly on their age. The cognitive functioning and the physical brain of a child keep on developing continuously until he reaches the age of puberty (Blakemore \& Choudhury, 2006). The researches further revealed that the brain undergoes considerable development during adolescence and into their early twenties (Cauffman \& Steinberg,2000). Thus, despite the fact that certain adolescents may appear to be as intelligent as adults in many ways, their ability to regulate their behavior is very limited. Their brains are unstable, neurologically immature, and incapable to respond effectively to situations that require reasoned decisions.

Apart from that, the researches on the cognitive functioning of adolescents reveal that there is much variability in terms of cognitive development and functioning between adolescence and adults. According to the researches, parts of the brain that control the functions of judgment, impulsive behaviors, and foresight, develop at a later stage of adolescence, particularly in the twenties rather than a teen year (Gur, 2005). Besides, researches on emotional development disclose that capacity of impulse control, which relates to the ability to respond in situations, among adolescents continuously progresses and extends well into middle or late adolescence. The studies, which are based on Magnetic Resonance Imaging (MRI) techniques, indicate the active and unstable development of adolescents' brains during the teenage phase has influenced the ability and function to process and respond to information (Giedd et al.,1999). Due to that reason, adolescents who are at this phase, incline to have poor impulse control, easily heed to peer pressure, be shortsighted, and influenced by emotions (Backus, 2012).

In short, these findings convincingly established the fact that there is a significant variation between children in acquiring neurological and cognitive, emotional, and developmental skills. These findings also have conclusively pointed out that children possess distinct cognitive and neurological developmental characteristics which make them different from adults. The variation in cognitive development and functioning provides a justifiable explanation of the inability of certain children in making reasonable, correct, and rational decisions during the interrogation process.

\section{The Susceptibility of Children During Police Interrogation}

Police interrogation is inherently compelling as the police are well-trained to direct compulsion toward extracting confessions and statements from the suspects. It is a well-known fact police investigation overwhelmingly involves elements of interpersonal tension, psychologically manipulative interrogation techniques, hostility, relentlessness, allegation, and exploitation (Lapp, 2017). In some cases, police have used numerous interrogation tactics to force the suspect to provide evidence, including coercion, false promise, proof making, and others. As highlighted in the previous section, research findings have deliberately pointed out children possess distinct cognitive and neurological developmental characteristics which make them different from adults. Their lack of neurological and cognitive capacities has made them vulnerable during the investigation process.

Despite this factual reality, it is surprising to note that studies show the police consistently resort to the similar mode and method of investigation applicable to adults, which involve the elements of confrontation, intimidation, repeated accusations, threats of harsh punishment, isolation, accusation and psychological manipulation when interrogating children (Hayley et al., 2016). Numerous researches disclosed that the interrogators have crossed the line by applying coercive and aggressive methods of interrogations to elicit confessions or statements from children (Cutler et al.,2014). The use of these improper methods of interrogation has heightened the likelihood of obtaining false and unreliable 
confessions or statements from children, which in turn, would potentially have detrimental legal effects against them.

In sum, the above discussion highlights the susceptibility of children during the interrogation process. Given their continuing cognitive and neurological development, children are put in an inherent disadvantage in withstanding police interrogation, the police should resort to a different and distinct method and procedure for interrogation of children, taking into consideration the fact that they are vulnerable fragile, immature, and lack of capacities as compared to adults.

\section{The Risk of Giving Self-Incriminatory} Statement and False Statement

It is crucial to highlight that the statements or confession given by children during the interrogation process is an important piece of legal evidence that may be used by or against them during the criminal process. There are various discussions relating to the detrimental legal consequence that might follow if children are unreasonably provoked to give false or selfincriminatory statements in them merely for the sake of avoiding the grueling and aggressive of interrogation.

\subsection{Self-incriminatory Statement}

The issue of protecting children during interrogation from giving self-incriminating statements is always a matter of concern on the part of various parties. Most laws recognize the right of any individual to abstain from giving selfincriminatory evidence. However, this right is merely asserted in general terms, without making any distinction between adults and children. Merely stating the specific right of children to selfincrimination in the laws is obviously inadequate to protect their rights. More often than not, children who are physically, emotionally, and psychologically insecure tend to waive their right not to give self-incriminatory evidence due to their limited capacity to make good decisions on their own (Leo,2017). They are prone to the police investigation process and procedure which are normally inherently coercive in nature. Some children may not even fully understand, let alone appreciate its impact and effect, the nature and importance of the law-abiding right to selfincrimination. Even if they broadly understand this right, they may be prevented from doing so by their low maturity, lack of forwarding orientation, unstable emotions, lack of psychological and mental strength, lack of life experience, and vulnerability to pressure (King, 2006). More often than not, children under investigation tend to make a self-incriminatory statement to end psychologically coercive interrogation due to their inability to fully realizing the consequences of their decisions (Feld, 2007).

\subsubsection{False Confession or Statement}

As regards to the issue of false confession and statement, there are various researches which revealed the tendency of suspected children who are unable to withstand with interrogation by the police and eventually provoked to give false confession and statement during the interrogation (Garrett, 2010). The inherent coercive and intimidating nature of custodial interrogation conducted by the police has induced vulnerable children to confess or admit to the crimes they never committed. In addition, the employment of the inappropriate techniques and tactics of interrogation including confrontation, intimidation, deception, false promise, fabrication of evidence, and others to pressure the suspect to give evidence have normally prompted to make false confessions and statements (Brudney, 2019). As a result, most of the children who are placed under the immense pressure of investigation prefer to hastily make false confessions and statements merely to get rid of the physically and emotionally stressful and grueling process of prolonged interrogation, naively thinking that they can undo the damaging effect their action later (Drizin \& Luloff, 2007). The researches further revealed that children under investigation tend to place more weight on the short term rather than long term effects of their decisions, due to their lack of experience and foreshortened sense of future (Houle, 2011). 


\subsubsection{Legal Consequences}

From a legal point of view, the effects of giving self- incriminatory and false confessions and statements are far-reaching and may work to detrimental to children. As regards to selfincriminatory statements, they may expose children to criminal prosecution. Basically, most of the legal systems permit self-incriminatory statements to be used by the prosecutors during the trial for the purpose proving the cases, challenging the credibility of the makers and others, subject to fulfilment of stringent conditions. On the other hand, false confessions and statements may result in wrongful convictions, the most devastating error in the criminal justice system. In the event children retract their statements given to the police during the process of interrogation, it could give rise to several legal consequences. Firstly, it could open to the possibility of being charged for giving false statement which is an offence under penal law. Apart from that, reliability and truthfulness of the child's evidence may be challenged if there is a conflict between his statement recorded during interrogation and oral testimony during the trial.

\subsection{Interrogation Under Malaysian Law}

As far as criminal processes involving children under the Malaysian legal system is concerned, it is mainly governed by two statutes, namely the Criminal Procedure Code (CPC), the Child Act 2001 and the Child Act (Amendment) 2016. The CPC is a general statute relating to criminal procedure. It states criminal procedures and processes at various stages, namely, pre-trial, trial, and post-trial stages. On the other hand, the Child Act 2001 is a specific statute governing child matters, including criminal processes. It should be noted that major amendment has been made to the Child Act 2001 in 2016, which resulted in the introduction of and the Child Act (Amendment) 2016. Therefore, the Child Act 2001 must be read together with the Child Act (Amendment) 2016. As far as criminal processes are concerned, it is provided under Part X and Part XI of the Child Act 2001. It is important to note that section 11(6) of the Child Act 2001 states that the provisions of the
CPC shall apply to the Court for Children in the absence of specific provisions providing for special or different procedures in the Child Act 2001. This simply means that that in the absence of a specific provision in the child Act 2001, the provision of the CPC will be automatically applied. As far as interrogations are concerned, a close reference to the child Act 2001 clearly shows that there are no specific provisions on the interrogation of children. As such reference on this matter need to be made to the relevant provisions of the CPC.

As far as interrogations are concerned, a close reference to the child Act 2001 clearly shows that there are no specific provisions on the interrogation of children. As such reference on this matter need to be made to the relevant provisions of the CPC. The application of the provisions of the CPC on child interrogation simply implies that similar principles and procedure of interrogation, which is originally designed for adults, are equally applicable to children.

\subsubsection{Procedure}

Provisions pertaining to interrogation is provided under section 111 to 115 of the CPC. Section 111 provides the power of the police to require the attendance of a person who is acquainted with the circumstances of the case under investigation. It is compulsory for a person to comply with the request from the police. Failure to comply with such a request may amount to a criminal offence under section 174 of the Penal Code. Section 112 confers power to police to examine orally any person acquainted with the facts and circumstances of the case under investigation. In other words, it permits the police to interview and record a statement from a person. Such a person is bound to answer all questions put to him truthfully, except any question which would have a tendency to implicate him to charge or penalty or forfeiture. Section 113 provides for the admission of statements recorded under section 112 in evidence. As a general principle, section 113 stipulates that any statement made by any person to the police in the course of the investigation shall be used in evidence. 
However, Para (3) and (5) of the same provision provides exceptional circumstances under which the statement recorded during the course investigation may be admitted in evidence. Para (3) that the statement made by the accused during the investigation may be admitted in evidence to support his defence during the trial. In addition, para (5) further states that the statement made by a person during the investigation may be admitted as evidence for the purpose of the impeachment proceeding.

\subsubsection{Issues}

Close examination of the provisions pertaining to the interrogation of children discloses that the current legal position is far from satisfactory. There are several grounds that make the existing laws on this particular matter are undesirable, particularly on children. These grounds are as follows;

\section{$i$ - $\quad$ Caution Requirement}

The existing law allows the statement of children to be recorded without the need to caution them on their rights not to give any self-incriminatory statement during an investigation. Section 111 makes it mandatory for children to submit to the request of the police to attend and allow their statements to be recorded. However, the provision does not make any mention at all regarding the need to caution children on their rights before their statements are recorded. The absence of the requirement of caution may be detrimental to children as they may be provoked to give a selfincriminatory statement and false statement, without knowing that they have privileges against giving a self-incriminatory statement as well as right to remain silent under the law. The absence of a requirement of caution also may prevent children from realizing and understand the legal consequences of giving a false statement or selfincriminatory statement. Both self-incriminatory statements and the false statement may expose children to criminal liability under criminal law. In addition, it is pertinent to note that though the statement of children recorded under section 112 of the CPC during the interrogation cannot be admitted as evidence, there are exceptions to this general principle. Section 113 of the CPC provides exceptional circumstances in which the statement recorded under section 112 is still admissible under the law for the purpose of impeachment proceeding and supporting the defence. Therefore, it is important to duly explain to children legal consequences that may follow in relation to their statements made to the police during interrogation. It should be emphasized that the legal process is complicated, tedious, and meticulous, involving various principles and procedural aspects. As such, it is absurd to expect children to know and understand their legal rights during interrogation and legal consequences that might follow, without someone duly caution and explain to them. In other words, the current position of law which does not impose a requirement on the police to explain and caution children on their rights before recording their statement is unfair and puts children in a disadvantaged position.

It is worth to note that international instruments on rights on children clearly emphasize that children shall be given due to procedural protections during the criminal processes. Article 40 of the United Nations Convention on the Rights of the Child (CRC) states that children shall not be compelled to give a self-incriminatory statement or confess to a crime. This requirement emphasizes that the process of the investigation involving children should strictly comply with the rule of law. It strictly prohibits any use of the element of torture, undue influence, coercion, inhuman or degrading treatment by the police for the purpose of interrogation or obtaining information or statement (Committee on the Rights of the Child, 2007). In elaborating this requirement, the Committee on the CRC stresses that it is vital for the state parties to specifically include in their respective juvenile law that any confession or statement obtained unlawful and improper method shall not be admissible in law. In conjunction with that, the Committee recommends the court and other judicial bodies of all legal systems to carefully consider the totality of the circumstances in determining the admissibility of child confession 
and statements. In the same vein, Rule 7 of the Beijing Rule also reinforce the requirement to safeguard the right of children during an investigation by stating the need for any juvenile justice systems to strictly uphold their fundamental right to remain silent. This right to remain silence prevents adverse inference to be drawn against children for silence and refusal to answer the question during the interrogation.

\section{ii- $\quad$ Legal Representation}

The right to legal representation during interrogation is very important for children. Currently, the provision relating right to counsel during the investigation is provided under section 28A of the CPC and section 83A of the Child Act (Amendment) 2016. Section 83(A) states the duty of the police to inform parents or guardians or relatives of children about the right to be represented. It requires the police officer to inform the parents, guardians, or relatives of the arrested children about the arrest and right of children to consult legal counsel of their own choice before any form of interrogation or statement is recorded. Besides, section 28A (2) (b) of the CPC provides that a police officer shall before commencing any form of questioning or recording of any statement from the arrested person, inform the person that they may communicate or attempt to communicate with a legal practitioner. It further mentions that the police are duty-bound to defer the questioning and recording of statements for a reasonable time to enable the arrested person to consult with his legal counsel. the police are also under the obligation to provide facilities for the purpose of consultation.

While the introduction of section 83(A) provision is a positive attempt to safeguard the right of children to representation, it seems to be vague and lacks clarity. Firstly, the provision does not guarantee the right of children to get access to legal representation immediately after arrest. Instead, the provision merely requires the police to inform them about the arrest and right of children to representation before the investigation or recording of a statement is initiated. It depends on parents, guardians, or relatives whether to arrange for the appointment of counsel for children or otherwise. In other words, the provision does not fully guarantee nor impose a legal requirement for arrested children to be mandatorily represented by counsels before interrogation or recording of a statement is initiated.

In addition, Para (4) section 83(A) provides the proviso to the effect that nothing in the section shall affect the power of the police officer to treat children in the manner provided by the CPC. The inclusion of this proviso allows the police to invoke exceptions under section 28(A) of the CPC to deny children from the right to representation. It should be noted that Para 8 of section 28(A) of the CPC provides certain exceptional circumstances in which the police may deny the right of the arrested person to legal counsel if the police reasonably believe that compliance with this requirement is likely to result in an accomplice of the arrested person taking steps to avoid apprehension or the concealment, fabrication, and destruction of evidence or the intimidation of witnesses. This position is not favorable as it prevents children from legal assistance before and during the interrogation process.

As a matter of comparison, the international instruments have recognized the right of children to legal counsel at any stage of criminal counsel. The right is considered as a fundamental which must be afforded to children without any qualification. Article 40(2)(b)(vii) of the CRC explicitly provides that any questioning or interrogation by the authority should not commence before children are given access and opportunity to consult their legal practitioners. The CRC further imposes an obligation on state parties to appoint legal counsel to represent children in the event they are unable to appoint legal counsel due to financial problems. The state parties are responsible to design a mechanism to provide free legal assistance for children (Committee on the Rights of the Child, 2007). The provisions to the same effect are also provided under Rule 15 Beijing Rules and Rule 18 of the Havana Rules.

iii- Participation of Parent or Guardians 
Current law does not provide any provision pertaining right of children to be accompanied by the parents or guardian or probation officers during the interrogation process (Mustaffa, 2016). Currently, there is no provision under the CPC or the Child Act 2001 which gives this privilege to children. In the context of police interrogation, incompetency of children may prevent them from adequately and effectively apprised of their rights during interrogation. This, in turn, may lead them to make a wrong decision such as giving false confession or self-incriminatory statements. Therefore, the presence of parent or guardian may effectively mitigate the potential for unchecked police pressure and ensure against false confessions from child suspects. The presence of parents during interrogation should not be viewed as interference with the process of interrogation as it is mainly aimed to provide emotional assistance and support to their children. This is in line with the requirement of the international instruments, which strongly recommend that children should be allowed to be accompanied by parents or guardians during the interrogation process (Committee on the Rights of the Child, 2007).

\section{Recommendations}

The discussion in the preceding section has disclosed that the current Malaysian law does not provide a specific procedure for the interrogation of children. In fact, there is no specific provision under the CPC or Child Act 2001 pertaining to the interrogation of children. As a result, general principles and procedures relating to interrogation provided under CPC, which are meant for adults, equally applicable to children, without any modification. This position is unsatisfactory as the CPC's provisions on these aspects are general and not specifically designed to cater to the need and interests of children. These provisions are inadequate and incomprehensive to protect the rights of children. Obviously, this practice is undesirable and deliberately does not correspond with the international standards set by international instruments. As such, it is recommended that amendments and improvements be made to the current Malaysian law pertaining to the interrogation of children. The recommendations are as follows;

\section{$i$ - Mandatory caution}

It is suggested that caution must be made compulsory before any evidence or statement of children is recorded. Children must be duly explained by the police of their legal rights, particularly right to remain silent, right not give a self-incriminatory statement and right to get access to a legal practitioner of their own choice. In addition, children must also be explained and reminded of the legal consequences of their statements which may be relied on and used during the trial processes. Procedure and principles regarding the administration of caution to children must be clearly elaborated. For example, there should be clear rules that caution must be explained in simple words and language understandable to children, the engagement of interpreters whenever necessary, and others.

\section{ii- Legal representation}

It is recommended that the right of children to consult legal practitioners of their own choices to be made mandatory. In the event children or their parents or guardians are unable to engage counsel due to financial difficulties, the government should automatically appoint the counsels for them and bear the legal costs. The presence of legal counsel is crucial as they will represent children and advise them throughout the whole process. The presence of counsel also may prevent children from being manipulated by the police during the grueling process of interrogation.

\section{iii- $\quad$ Specific procedure}

It is crucial for the government to formulate specials rules and procedures governing criminal processes of children, including the interrogation process. Though the government has introduced the Child Act 2001 which is expected to govern all legal matters relating to children, it is crystal clear that this Act is incomprehensive. As far as the interrogation process is concerned, there is no specific provision at all on the interrogation of 
children provided under this Act. As a result, reference on this matter has to be made to the CPC, which are originally designed to address the criminal process involving adults. The application of provisions of the CPC on children is not desirable as the CPC does not make any distinction between the interrogation of children and adults. This legal position and practice are undesirable as it is obviously failed to conform with the international standards fixed by the international instruments. Besides, this legal position does not correspond with the overwhelming findings of numerous psychologists and scientists that conclude children and adults are fundamentally different in terms of mental, physical, and emotional capacities as well as maturity and experiences.

Therefore, it is timely to introduce special rules and procedures for the interrogation of children. Among the aspects that may be considered to be introduced are imposing limited lengths of interrogation period, allowing child experts to assist the police, allowing the presence of parent or guardians, and mandatory recording and videotaping of the whole process of interrogation.

\section{Conclusion}

Current Malaysian laws on the interrogation of children predominantly treat children in a similar way as adults despite the recognition of the need to provide them with special protections. The absence of specific provisions on the interrogation of children under the relevant statutes has resulted in application similar rules and procedures for both children and adults. This position is undesirable as children, due to their unique incompetence, incapacities, lack of experience, and vulnerability require additional protection in the context of police interrogation. This legal issue should be effectively addressed through legislative reform. There is an urgent need for the Malaysian juvenile justice system to specifically provide a set of procedural safeguards to protect children during the interrogation process.

\section{ACKNOWLEDGMENT}

This research is funded by the Fundamental Research Grant Scheme No. FRGS/1/2019/SSI10/UNISZA/02/1.

\section{REFERENCES}

[1] Backus, M.S. (2012). Achieving Fundamental Fairness for Oklahoma's Children: The Role for Competency in Child Proceedings. Oklahoma Law Review, 65, 41-73.

[2] Blakemore, S-J. \& Choudhury S. (2006). Development of the adolescent brain: Implications for executive function and social cognition. Journal of Child Psychology and Psychiatry, 47(3), 296312. $\quad$ https://doi.org/10.1111/j.14697610.2006.01611.x

[3] Brudney, H. (2019). Confessions of teenage defendant: Why new legal rule is necessary to Buck, T., Gillespie, A., Ross, L. and Sargent, S. (2014). International Child Law. $2^{\text {nd }}$ ed.

[4] Cauffman, E. \& Steinberg L. (2000). Immaturity of judgment in adolescence: Why for executive function and social cognition. Journal of Child Psychology and Psychiatry, 47(3), 296-312.

[5] Committee on the Rights of the Child, General Comment No 10: Children's rights in child Committee on the Rights of the Child, General Comment No 10: Children's Rights in Confession. UMKC Law Review, 82, 589- 622. Convictions? Northern Kentucky Law Review, 32(3), 257-322.

[6] Cutler, B., Findley, K. \& Loney, B. (2014). Expert Testimony on Interrogation and False Confession. UMKC Law Review, 82, 589- 622.

[7] Drizin, S.A. \& Luloff, G. (2007). Are Child Courts A Breeding Ground for Wrongful Due Process. The Dartmouth Law Journal, 9(3), 86-119.

[8] Feld, B.C. (2007). Police Interrogation of Children: An Empirical Study of Policy and for Competency 
in Child Proceedings. Oklahoma Law Review, 65, 41-73.

[9] Garrett, B.L. (2010). The Substance of False Confessions. Stanford Law Review, 62, 1051- Gazett, 103-117.

[10] Giedd, J.N. et al. (1999). Brain Development During Childhood and Adolescence: A guide the evaluation of juvenile confessions. Southern California Law Review, 92(5), 1235-1272.

[11] Gur, R.C. (2005). Brain maturation and the execution of children. University of Pennsylvania Gazett, 103-117.

[12] Hayley M. D. Cleary \& Todd, C. W. (2016) Police Training in Interviewing and Interrogation Methods: A Comparison of Techniques Used with Adult and Juvenile Suspects. Law \&amp; Human Behavior, 40, 270-291.

[13] Houle, S.R. (2011). Juvenile justice is Not Just Kid Stuff: The Forgotten Side of Fairness and justice, CRC/C/GC/10, 25 ${ }^{\text {th }}$ April 2007, para. 56. Juvenile Justice, CRC/C/GC/10, 25 ${ }^{\text {th }}$ April 2007, para. 49.

[14] King, K.J. (2006). Waiving Childhood Goodbye: How Child Courts Fail to Protect Children From Unknowing, Unintelligent, and Involuntary Waivers of Miranda Rights. Wisconsin Law Review, 431478.

[15] Lapp, K. (2017) Taking Back Juvenile Confessions. UCLA Law Review, 64, 902966.

[16] Leo, R. A. (2017). Police interrogation, false confessions, and alleged child abuse cases. Little Too Late?. Asian Journal of Criminology, 11(2), 135-153.

[17] Mustaffa, A. (2016). Diversion Under Malaysian Juvenile Justice System: a Case of Too Nations Convention on the Rights of the Child. In: Alen, A. et al., eds., Leiden, Boston: Martinus Nijhoff Publishers. Practice. The Journal of Criminal Law \& Criminology, 97, 219-316.University of Michigan Journal of Law Reform, 50(3), 693-722. 